\title{
MENUMBUHKAN SIKAP PEDULI PADA ANAK MELALUI INTERAKSI KEGIATAN SOSIAL
}

\author{
A.Tabi'in \\ Dosen Fakultas Tarbiyah dan Ilmu Keguruan IAIN Pekalongan \\ e-mail : ahmadtabiin6@gmail.com
}

\begin{abstract}
Attitudes and actions of caring to others need to be enhanced for children, particularly young learners. It indicates that social care is required to be built so that children do not possess negative behavior such as individualism, arrogance, and lack of cooperation. Social care refers to attitudes and actions that are demonstratedtoprovide assistance to those who need help. Therefore, it demands every individual to be able to pay attention to where he or she lives. Social care on children can be defined as the behavior that is needed to understand others' conditions and needs. The building of this behavior should be embedded with sustainable practices. They, for instance, are accustomed to deal with real situations. Additionally, their parents or other family members should show good modeling to the children. It suggests that these practices requirethe roles of their parents, other family members, and teachers. One of the attempts to build social care to children is by integrating this kind of behavior in their daily lives so as to make them get accustomed to the attitudes and actions.
\end{abstract}

Keywords : Building,Social Care, Children.

Abstrak : Sikap dan tindakan yang selalu ingin memberi bantuan perlu dikembangkan pada diri anak, terutama anak prasekolah. Peduli sosial perlu dikembangkan agar anak tidak memiliki sifat negatif, seperti sombong, acuh tak acuh, individualisme, masa bodoh terhadap masalah sosial, pilih-pilih teman dan lunturnya budaya gotong-royong. Peduli sosial adalah sikap dan tindakan yang selalu ingin memberi bantuan pada orang lain dan masyarakat yang membutuhkan. Dari sinilah kepedulian sosial menuntut kepada setiap individu agar mampu memperhatikan lingkungan tempat tinggalnya atau masyarakat. Peduli sosial pada anak bisa diartikan sebagai sikap 
mampu memahami kondisi orang lain sesuai dengan pandangan orang lain tersebut, bukan sesuai dengan pandangannya sendiri. Pemahaman sikap ini harus dengan latihan-latihan dengan cara anak dihadapkan pada situasi nyata, serta pemberian contoh dari keluarga dan orangtua anak. Latihan-latihan ini tentunya memerlukan sosok orang tua, guru untuk mendampinginya.cara guru, orang tua dalam mengembangkan sikap peduli sosial adalah denganmengintegrasikannya ke dalam kehidupan sehari-hari guna untuk pembiasaan anak.

Kata kunci:Membangun, Peduli Sosial, Anak.

\section{A. PENDAHULUAN}

Manusia sebagai makhluk sosial tentu tidak mungkin bisa memisahkan hidupnya dengan manusia lain. Sudah bukan rahasia lagi bahwa segala bentuk kebudayaan, tatanan hidup, dan sistem kemasyarakatan terbentuk karena interaksi dan benturan kepentingan antara satu manusia dengan manusia lainnya. Keutuhan manusia akan tercapai apabila manusia sanggup menyelaraskan perannya sebagai makhluk ekonomi dan sosial. Sebagai makhluk sosial (homo socialis), manusia tidak hanya mengandalkan kekuatannya sendiri, tetapi membutuhkan manusia lain dalam beberapa hal tertentu, dan haruslah saling menghormati, mengasihi, serta peduli terhadap berbagai macam keadaan disekitarnya.

Manusia adalah makhluk sosial, yang artinya manusia itu tidak akan bisa hidup sendiri tanpa bantuan orang lain. Namun terkadang hati manusia terbesit rasa sombong dan terlalu membanggakan diri sehingga ia lupa akan dirinya sendiri, siapa dia dan untuk apa dia hidup. Dalam hidup bermasyarakat perlu adanya kepedulian antara manusia satu dengan manusia lainnya.Rasulullah pun mengajak umatnya untuk peduli kepada sesama makhluk Allah, dan saling bergotong-royong untuk saling membantu. Dan meringankan penderitaan orang lain sangat dianjurkan untuk umat Rasulullah.

Manusia sebagai makhluk sosial tentu tidak mungkin bisa memisahkan hidupnya dengan manusia lain. Sudah bukan rahasia lagi bahwa segala bentuk kebudayaan, tatanan hidup, dan sistem 
kemasyarakatan terbentuk karena interaksi dan benturan kepentingan antara satu manusia dengan manusia lainnya. Sejak zaman prasejarah hingga sejarah, manusia telah disibukkan dengan keterciptaan berbagai aturan dan norma dalam kehidupan berkelompok mereka.Keutuhan manusia akan tercapai apabila manusia sanggup menyelaraskan perannya sebagai makhluk ekonomi dan sosial. Sebagai makhluk sosial (homo socialis), manusia tidak hanya mengandalkan kekuatannya sendiri, tetapi membutuhkan manusia lain dalam beberapa hal tertentu, dan haruslah saling menghormati, mengasihi, serta peduli terhadap berbagai macam keadaan disekitarnya.

Anak usia dini adalah sosok individu yang sedang menjalani suatu proses perkembangan denganpesat dan fundamental baik kehidupan selanjutnya. Anak usia dini sendiri adalah mereka yang memilikirentan usia antara 0-8 tahun ada yang mengatakan 0-6 tahun. Pada masa ini terjadilah proses pertumbuhan dan perkembangan dalamberbagai aspek, salah satu diantaranya adalah aspek dalam interaksi sosial.

Interaksi sosial (Soekanto, 1992: 67) merupakanhubunganhubungan sosial yang menyangkuthubungan antar individu, individu dengan kelompok, dan kelompok dengan kelompok. Interaksi sosial akanterjadi jika adanya sebuah kontak sosial dan adanya komunikasi. Interaksi sosial merupakan kunci darisemua kehidupan sosial, oleh karena itu tanpa interaksi sosial, tak akan mungkin ada kehidupan bersama. Padaanak usia dini interaksi sosial memanglah sangat dibutuhkan karena anak nantinya akan diajarkanbagaimana hidup bermasyarakat, lalu anak juga akan diajarkan berbagai peran yang nantinya akanmenjadiindentifikasi dirinya, selain itu pula saat melakukaninterasi sosial anak akan memperoleh berbagaiinformasi yang ada disekitarnya

Pada era sekarang ini anak-anak perlu dikenalkan bahkan di ajarkan mengenai kepedulian sosial, agar pada suatu saat nanti anak mempunyai kepekaan terhadap orang yang membutuhkan, dengan dikenalkan sifat kepedulian tentunya anak akan mengenal dan memahami arti penting dari kepedulian terhadap sesama karena itu akan bermanfaat bagi anak-anak tersebut pada khususnya dan pada bangsa dan negara manakala itu di ajarkan secara serius. 
Anak-anak adalah kebanggaan bagi orang tuanya. Anak yang memiliki perilaku baik merupakan kebahagiaan bagi orang tua. Sebaliknya anak yang berperilaku buruk di masyarakat merupakan kegagalan bagi orang tua. Orang tua tentu mengharapkan sang anak mampu bersosialisasi dengan baik serta memiliki kepedulian sosial yang tinggi. Oleh karena itu sifat peduli terhadap sosial perlu ditanamkan sejak dini. Pengetahuan orang tua mengenai pentingnya menanamkan kepedulian sosial pada anak dapat menentukan sifat anak suatu saat nanti, apakah sang anak akan menjadi pribadi yang peduli terhadap lingkungan sosial atau menjadi pribadi yang acuh terhadap lingkungan sosial.

Kepribadian anak setelah dewasa tidak bisa lepas dari bagaimana pola pendidikan yang diterapkan orang tua kepada anak di usia dini. Dengan mengarahkannya semenjak usia dini, maka kemungkinan besar anak menjadi pribadi yang diharapkan oleh orang tua menjadi lebih besar, dan tentunya setiap orang tua menginginkan anaknya menjadi pribadi yang sebaik-baiknya bahkan lebih dari orang tuanya.

Ada begitu banyak nilai-nilai kebaikan yang sebaiknya ditanamkan kepada diri anak, yakni kepedulian terhadap sesama. Seiring dengan berkembangnya waktu dan zaman, rasa kepedulian banyak manusia terhadap sesamanya mulai banyak berubah dan meluntur, sehingga dengan menanamkan rasa peduli terhadap sesamanya, maka di masa depan lingkungan anak anda tumbuh dan hidup tetap menjunjung tinggi rasa kepedulian yang besar bagi sesama.

Sikap sayang sesama dapat dilatih kepada anak dengan cara, misalnya, memberi tahu anak bagaimana harus bersikap saat berteman. Mereka juga harus diajarkan untuk mengutarakan perasaan dengan kata-kata. Bagi anak, hal itu sangat penting karena saat anak-anak segala sesuatu ingin diketahui.Hal lain yang harus diajarkan orangtua kepada anak adalah mengajarkan mereka untuk menolak perilaku yang bertentangan dengan kasih sayang salah satunya yaitu mengejarkan kepedulian terhadap sesama. 


\section{B. PEMBAHASAN}

\section{a. Pentingnya Mengajarkan Kepedulian Sosial Pada Anak}

\section{a. Kepedulian sosial}

Manusia hidup di dunia ini pasti membutuhkan manusia lain untuk melangsungkan kehidupannya, karena pada dasarnya manusia merupakan makhluk sosial. Menurut Buchari Alma, dkk. makhluk sosial berarti bahwa hidup menyendiri tetapi sebagian besar hidupnya saling ketergantungan, yang pada akhirnya akan tercapai keseimbangan relatif. Maka dari itu, seharusnya manusia memiliki kepedulian sosial terhadap sesama agar tercipta keseimbangan dalam kehidupan (Buchari, 2010: 201).

Darmiyati Zuchdi (2011: 170) menjelaskan bahwa, peduli sosial merupakan sikap dan tindakan yang selalu ingin memberi bantuan kepada masyarakat yang membutuhkan. Berbicara masalah kepedulian sosial maka tak lepas dari kesadaran sosial. Kesadaran sosial merupakan kemampuan untuk memahami arti dari situasi sosial. Hal tersebut sangat tergantung dari bagaimana empati terhadap orang lain. Berdasarkan beberapa pendapat yang tertera diatas dapat disimpulkan bahwa, kepedulian sosial merupakan sikap selalu ingin membantu orang lain yang membutuhkan dan dilandasi oleh rasa kesadaran (Malik, 2008: 423).

Untuk itu kepedulian sosial adalah perasaan bertanggung jawab atas kesulitan yang dihadapi oleh orang lain di mana seseorang terdorong untuk melakukan sesuatu untuk mengatasinya. "Kepedulian Sosial" dalam kehidupan bermasyarakat lebih kental diartikan sebagai perilaku baik seseorang terhadap orang lain di sekitarnya. Kepedulian sosial dimulai dari kemauan "memberi" bukan "menerima". Bagaimana ajaran Nabi Muhammad untuk mengasihi yang kecil dan Menghormati yang besar; orang-orang kelompok 'besar' hendaknya mengasihi dan menyayangi orang-orang kelompok 'kecil', sebaliknya orang 'kecil' agar mampu memposisikan diri, menghormati, dan memberikan hak kelompok 'besar'.

Berjiwa sosial dan senang membantu merupakan sebuah ajaran yang universal dan dianjurkan oleh semua agama. Meski begitu, kepekaan untuk melakukan semua itu tidak bisa tumbuh begitu saja pada diri setiap orang karena membutuhkan proses melatih dan mendidik. Memiliki jiwa peduli terhadap sesama sangat 


\section{MENUMBUHKAN SIKAP PEDULI PADA ANAK...}

penting bagi setiap orang karena kita tidak bisa hidup sendirian di dunia ini. Faktor lingkungan tentunya sangat berpengaruh dalam proses menumbuhkan jiwa kepedulian sosial. Lingkungan terdekat seperti keluarga, teman-teman, dan lingkungan masyarakat tempat dimana kita tumbuh dan bersosialisasi sangat berpengaruh besar dalam menentukan tingkat kepedulian sosial.

Semua nilai-nilai tentang kepedulian sosial kita dapatkan melalui lingkungan. Kepedulian sosial yang dimaksud bukanlah untuk mencampuri urusan orang lain, tetapi lebih pada membantu menyelesaikan permasalahan yang di hadapi orang lain dengan tujuan kebaikan dan perdamaian. Nilai-nilai yang tertanam itulah yang nanti akan menjadi suara hati kita untuk selalu membantu dan menjaga sesama.

\section{b. Peduli Sosial Salah Satu Pendidikan Karakter}

Dalam pendidikan karakter terdapat beberapa karakter yang ingin dikembangkan oleh pemerintah dan satuan pendidikan, antara lain karakter religius, kejujuran, toleransi, disiplin, kerja keras, kreatif, mandiri, demokratis, rasa ingin tahu, semangat kebangsaan, cinta tanah air, menghargai prestasi, bersahabat/komunikatif, cinta damai, gemar membaca, peduli akan lingkungan, peduli sosial dan bertanggung jawab.

Ada sekitar 18 karakter yang diusulkan oleh pemerintah untuk dikembangkan terhadap anak. Salah satu karakter terpenting yang perlu untuk dikembangkan oleh guru maupun orang tua adalah karakter peduli sosial. Menurut Retno Listyarti (2012: 7) peduli sosial adalah sikap dan tindakan yang selalu ingin memberi bantuan pada orang lain dan masyarakat yang membutuhkan. Sedangkan menurut KBBI (2008: 1036) yang dimaksud dengan peduli sosial adalah sikap mengindahkan (memprihatinkan) sesuatu yang terjadi dalam masyarakat.

Sedangkan menurut Pusat Studi PAUD Lembaga Penelitian Universitas Negeri Yogyakarta, peduli sosial atau peduli terhadap sesama adalah suatu sikap anak yang mampu memahami kondisi orang lain sesuai dengan pandangan orang lain tersebut, bukan sesuai dengan pandangannya sendiri. Pemahaman sikap ini harus 
dengan latihan-latihan dengan cara anak dihadapkan pada situasi nyata (PusatStudi PAUD, 2009: 15-16).

Di dalam kepedulian sosial, peserta didik diharapkan mampu mengembangkan sikap dan tindakan yang selalu ingin memberi bantuan kepada orang lain. Karakter peduli sosial ini dibutuhkan peserta didik sebagai bekal untuk hidup di lingkungan sosialnya. Sedangkan unsur sosial yang terpenting yaitu interaksi di antara manusia (S. Nasution, 1983: 14). Hal yang sangat ditakuti saat peserta didik berinteraksi dengan peserta didik yang lain adalah pilih-pilih teman. Anak akan cenderung memilih teman yang satu golongan dengannya. Misalnya anak yang termasuk golongan atas hanya mau berteman dengan anak yang segolongan dengannya. Sedangkan anak yang memiliki golongan rendah merasa malu dan enggan untuk berteman dengan anak yang bergolongan lebih tinggi.

Pada kenyataannya sistem golongan sosial menimbulkan batas-batas dan rintangan ekonomi, kultural, dan sosial yang mencegah pergaulan dengan golongan-golongan lain (S. Nasution, 1983). Salah satu tujuan dari pendidikan karakter adalah untuk menghindari terjadinya batas-batas pergaulan dalam golongangolongan yang ada di lingkungan kelas tersebut.

Tujuan yang lain dari pendidikan karakter adalah untuk membentuk bangsa yang tangguh, kompetitif, berakhlak mulia, bermoral, bertoleran, bergotong-royong, berjiwa patriotik, berkembang dinamis, berorientasi ilmu pengetahuan dan teknologi yang semuanya dijiwai oleh iman dan takwa kepada Tuhan Yang Maha Esa Sri Narwanti, (2011: 16). Sikap gotong royong inilah yang akan dibangun di dalam diri peserta didik di sekolah yang diharapkan dapat menghapuskan pergaulan yang selalu pilih- pilih.

\section{c. Mengajarkan Kepedulian Sosial Pada Anak}

Anak-anak pada usia dini memiliki kecerdasan dan daya tangkap yang sangat cepat. Anak pada usia sekolah dapat menangkap hal-hal baru dan menanamkan dalam benaknya hingga dewasa. Pembelajaran pada anak usia ini adalah pembelajaran yang paling efektif dan paling diingat anak sehingga penting ditanamkan segala hal baik termasuk kepedulian sosial. Jika anda sebagai orang tua mengajarinya peduli terhadap sosial pada usia ini maka anak anda 


\section{MENUMBUHKAN SIKAP PEDULI PADA ANAK...}

akan mengingatnya hingga dewasa dan akan menjadi anak yang peduli terhadap sesamanya. Pentingnya menanamkan kepedulian sosial pada anak harus diketahui oleh orang tua agar orang tua dapat mengarahkan anak menjadi orang yang peduli terhadap masyarakat ketika dewasa.

Pada usia ini juga anak sudah dapat membedakan yang baik dan buruk serta berfikir dengan logika. Pembelajaran pada masa ini sangat efektif karena anda dapat dengan mudah mengajarinya karena anak anda pun sudah mulai tahu sikap peduli terhadap sosial merupakan tindakan yang terpuji. Pemahaman yang diberikan oleh orang tua pada usia ini berguna untuk mengarahkan dan memberi petunjuk bagi anak mengenai hal yang baik serta hal yang tidak baik untuk dilakukan.

\section{d. Mengajari Anak Untuk Peduli Sosial}

a. Berikan pemahaman

Pada usia ini berikan pemahaman terhadap anak anda mengenai pentingnya kepedulian sosial. Pemahaman ini perlu diberikan karena anak pada usia tersebut logikanya telah berkembang. Anak membutuhkan alasan yang logis mengapa di harus peduli terhadap lingkungan sosialnya. Anda dapat menjelaskan pentingnya kepedulian sosial secara logis dengan dipadukan dengan secara agamis sehingga anak anda dapat mengetahui tuntunan agama secara lebih praktikal.

b. Berikan contoh

Tidak hanya pemahaman, berikan juga contoh pada anak anda. Anak sangat mudah meniru orang tuanya, sehingga jika anda mencontohkan perilaku yang peduli terhadap sosial anak anda akan mudah menirukannya.

c. Berikan stimulus berupa hadiah serta puji

Anda perlu ingat anak juga membutuhkan pujian dan hadiah. Tunjukan pada anak anda bahwa bersikap peduli terhadap lingkungan sosial merupakan hal terpuji dengan memberinya pujian. Berikan pula stimulan untuk bersikap peduli terhadap sosial seperti hadiah saat anak anda mau membagi mainannya pada sesama dan sebagainya.

d. Berikan hukuman dan pengarahan, 
Selain pujian anak juga harus diberikan hukuman jika melakukan perilaku yang acuh terhadap sosial. Hukuman tersebut haruslah bersifat mengarahkan dan menunjukkan bahwa perilakunya keliru. Anda harus ingat hukuman untuk anak tidak boleh disamakan dengan hukuman untuk orang dewasa. Hindari kekerasan, dan tetap tunjukkan rasa sayang anda saat menghukumnya.

e. Perhatikan anak

Yang paling penting adalah perhatian anda terhadap anak anda. Anak anda membutuhkan pengakuan saat berbuat baik. Jika anda tidak memberinya perhatian terutama saat berbuat baik maka lama kelamaan dia tidak ingin berbuat baik karena tidak ada bedanya dia berbuat baik maupun buruk.

Sebagai orang tua hendaknya anda tahu mengenai pentingnya Menanamkan Kepedulian Sosial Pada Anak. Pemahaman anak mengenai pentingnya kepedulian sosial dapatmenjadikan anak anda pribadi yang peduli terhadap sosial kelak. Langkah langkah untuk mengajarinya sederhana, anda hanya cukup memberinya pengertian, contoh serta rangsangan sehingga anak anda terbiasa dengan sikap peduli terhadap lingkungan sosial.

\section{e. Bentuk Kepedulian Sosial Yang Dapat Di Ajarkan Kepada Anak}

Bentuk-bentuk kepedulian sosial dapat dibedakan berdasarkan lingkungan. Lingkungan yang dimaksud merupakan lingkungan dimana seseorang hidup dan berinteraksi dengan orang lain yang biasa disebut lingkungan sosial. Menurut Elly M. Setiadi, lingkungan sosial merujuk pada lingkungan dimana seseorang melakukan interaksi sosial, baik dengan anggota keluarga, teman, dan kelompok sosial lain yang lebih besar (2012: 66). Buchari Alma, dkk (2010: 205-208) membagi bentuk-bentuk kepedulian berdasarkan lingkungannya, yaitu:

a. Lingkungan Keluarga

Keluarga merupakan lingkungan sosial terkecil yang dialami oleh seorang manusia. Lingkungan inilah yang pertama kali mengajarkan manusia bagaimana berintaeraksi. Abu Ahmadi \& Uhbiyati menjelaskan bahwa interaksi tersebut dapat diwujudkan 


\section{MENUMBUHKAN SIKAP PEDULI PADA ANAK...}

dengan air muka, gerak-gerik dan suara. Anak belajar memahami gerak-gerik dan air muka orang lain. Hal ini penting sekali artinya, lebih-lebih untuk perkembangan anak selanjutnya, karena dengan belajar memahami gerak-gerik dan air muka seseorang maka anak tersebut telah belajar memahami keadaan orang lain. Hal yang paling penting diketahui bahwa lingkungan rumah itu akan membawa perkembangan perasaan sosial yang pertama (Abu Ahmadi \& Uhbiyati, 2001). Misalnya perasaan simpati anak kepada orang dewasa (orang tua) akan muncul ketika anak merasakan simpati karena telah diurus dan dirawat dengan sebaik-baiknya. Dari perasaan simpati itu, tumbuhlah rasa cinta dan kasih sayang anak kepada orang tua dan anggota keluarga yang lain, sehingga akan timbul sikap saling peduli.

Fenomena lunturnya nilai-nilai kepedulian sesama anggota keluarga dapat dilihat dari maraknya aksi kekerasan dalam rumah tangga (KDRT) yang sering terungkap di media-media. Sebenarnya, sikap saling peduli terhadap sesama anggota keluarga dapat dipelihara dengan cara saling mengingatkan, mengajak pada hal-hal yang baik, seperti: mengajak beribadah, makan bersama, membersihkan rumah, berolahraga, dan hal-hal lain yang dapat memupuk rasa persaudaraan dalam keluarga.Keluarga yang merupakan lingkungan sosial terkecil seharusnya dipelihara keharmonisannya. Keharmonisan dalam keluarga menjadi menjadi sangat vital dalam pembentukan sikap peduli sosial karena akansangat mendukung pada tingkatan masyarakat yang lebih luas termasuk dampaknya bagi negara.

b. Lingkungan Masyarakat

Lingkungan masyarakat pedesaan yang masih memiliki tradisi yang kuat masih tertanam sikap kepedulian sosial yang sangat erat. Ketika ada suatu kegiatan yang dilakukan oleh satu keluarga, maka keluarga lain dengan tanpa imbalan akan segera membantu dengan berbagai cara. Misalnya saat mau mendirikan rumah, anggota keluarga yang lain menyempatkan diri untuk berusaha membantunya.Situasi yang berbeda dapat dirasakan pada lingkungan masyarakat perkotaan. Jarang sekali kita lihat pemandangan yang menggambarkan kepedulian sosial antar 
warga. Sikap individualisme lebih ditonjolkan dibandingkan dengan sikap sosialnya.

Menurut Buchari Alma, dkk (2010: 206) beberapa hal yang menggambarkan lunturnya kepedulian sosial diantaranya:

1) Menjadi penonton saat terjadi bencana, bukannya membantu.

2) Sikap acuh tak acuh pada tetangga.

3) Tidak ikut serta dalam kegiatan di masyarakat.

Sebenarnya di dalam masyarakat tumbuh berbagai macam kelompok sosial. Menurut Abu Ahmadi \& Nur Uhbiyati (2007), kelompok sosial merupakan unsur-unsur pelaku atau pelaksana asas pendidikan yang secara sengaja dan sadar membawa masyarakat kepada kedewasaan, baik secara jasmani maupun rohaniyang tercermin pada perbuatan dan sikap kepribadian warga masyarakat. Contoh kelompok sosial itu adalah karang taruna, remaja masjid, PKK dan sebagainya.

c. Di Lingkungan Sekolah

Sekolah tidak hanya sebagai tempat untuk belajar meningkatkan kemampuan intelektual, akan tetapi juga membantu anak untuk dapat mengembangkan emosi, berbudaya, bermoral, bermasyarakat, dan kemampuan fisiknya (Tim Dosen Jurusan Filasafat dan Sosiologi Pendidikan, 2000: IV9). Young Pai dalam Arif Rohman (2009: 201) berpendapat bahwa sekolah memiliki dua fungsi utama yaitu, sebagai instrumen untuk mentramsmisikan nilai-nilai sosial masyarakat (to transmit sociental values) dan sebagai agen untuk transformasi sosial (to be the agent of social transform) (Rohman, 2009: 201). Sedangkan Abu Ahmadi \& Uhbiyati (2001) menjelaskan bahwa, fungsi sekolah sebagai lembaga sosial adalah membentuk manusia sosial yang dapat bergaul dengan sesama manusia secara serasi walaupun terdapat unsur

perbedaan tingkat sosial ekonominya, perbedaan agama, ras, peradaban, bahasa dan lain sebagainya.

Menurut pernyataan diatas dapat dikatakan bahwa, sekolah bukan hanya tempat untuk belajar meningkatkan kemampuan intelektual, akan tetapi juga mengembangkan dan memperluas pengalaman sosial anak agar dapat bergaul dengan orang lain di dalam masyarakat.Selain sebagi tempat 
mengembangkan dan memperluas pengalaman sosial anak, sekolah dapat juga membantu memecahkan masalah-masalah sosial. Seperti pendapat Ary H. Gunawan (2000: 68) yang menyatakan bahwa, dengan pendidikan diharapkan berbagai masalah sosial yang dihadapi siswa dapat diatasi dengan pemikiran-pemikiran tingkat intelektual yang tinggi melalui analisis akademis.Fuad Ihsan (2003: 83) juga berpendapat bahwa, di sekolah tugas pendidik adalah memperbaiki sikap siswa yang cenderung kurang dalam pergaulannya dan mengarahkannya pada pergaulan sosial.

Di sekolah, anak dapat berinteraksi dengan guru beserta bahan-bahan pendidikan dan pengajaran, teman-teman peserta didik lainnya, serta pegawai-pegawai tata usaha. Selain itu, siswa memperoleh pendidikan formal di sekolah berupa pembentukan nilai-nilai, pengetahuan, ketrampilan dan sikap terhadap bidang studi/mata pelajaran. .Berinteraksi dan bergaul dengan orang lain dapat ditunjukkan dengan berbagai cara, salah satunya adalah dengan menunjukkan sikap peduli terhadap sesama. Di dalam lingkup persekolahan, sikap kepedulian siswa dapat ditunjukkan melalui peduli terhadap siswa lain, guru, dan lingkungan yang berada di sekitar sekolah.Rasa peduli sosial di lingkungansekolah dapat ditunjukkan dengan perilaku saling membantu, saling menyapa, dan saling menghormati antar warga sekolah. Perilaku ini tidak sebatas pada siswa dengan siswa, atau guru dengan guru, melainkan harus ditunjukkan oleh semua warga sekolah yang termasuk di dalamnya.;

\section{f. Faktor Yang Menyebabkan Turunnya Kepedulian Sosial Pada Anak}

Menurut Buchari Alma, (2010: 209), faktor yang menyebabkan turunnya kepedulian sosial adalah karena kemajuan teknologi. Teknologi tersebut diantaranya:

a. Bermain Internet

Dunia maya yang sangat transparan dalam mencari suatu informasi malah menjadi sarana yang menyebabkan lunturnya kepedulian sosial. Manusia menjadi lupa waktu karena terlalu asyik menjelajah dunia maya. Tanpa disadari mereka lupa dan 
tidak menghiraukan lingkungan masyarakat sekitar, sehingga rasa peduli terhadap lingkungan sekitar kalah oleh sikap individualisme yang terbentuk dari kegiatan tersebut.

b. Sarana hiburan (Game)

Seiring dengan kemajuan teknologi maka dunia hiburan akan turut berkembang. Karakter anak-anak yang suka bermain akan menjadikan anak sebagai korban dalam perkembangan sarana hiburan. Anak yang terlalu lama bermain game akan mempengaruhi kepeduliannya terhadap sesama. Mereka tidak berhubungan langsung dengan sesamanya. Hal tersebut mengharuskan orang tua untukmeningkatkan pengawasan terhadap anak-anaknya.

c. Tayangan TV

Televisi merupakan salah satu sarana untuk mencari hiburan dan memperoleh informasi yang up to date, namun sekarang ini banyak tayangan di TV yang tidak mendidik anak-anak. diantaranya adalah acaragosip dan sinetron. Secara tidak langsung penonton diajari berbohong, memfitnah orang lain, menghardik orang tua, dan tayangannya jauh dari realita kehidupan masyarakat Indonesia pada umumnya.

d. Masuknya budaya barat

Pengaruh budaya barat yang bersifat immaterial dan cenderung berseberangan dengan budaya timur akan mengakibatkan normanorma dan tata nilai kepedulian yang semakin berkurang. Masyarakat yang kehilangan rasa kepedulian akan menjadi tidak peka terhadap lingkungan sosialnya, dan akhirnya dapat menghasilkan sistem sosial yang apatis

Pendapat lain dikemukakan Hera Lestari Malik, dkk (2008: 4.17) yang menyatakan bahwa, tingkat sosialisasi individu yang rendah disebabkan oleh kegagalan pada salah satu proses sosialisasi. Proses sosialisasi tersebut adalah berikut ini:

a. Belajar untuk bertingkah laku sesuai dengan cara/ norma yang berlaku. Setiap kelompok sosial memiliki dasar mengenai tingkah laku yang perlu dimiliki anggotanya. Untuk bersosialisasi, anak tidak hanya mengerti apakah tingkah laku ini diterima, tetapi juga memberi contoh tingkah laku mereka selama masih dapat diterima kelompok. 


\section{MENUMBUHKAN SIKAP PEDULI PADA ANAK...}

b. Bermain sesuai dengan peran sosial yang diharapkan setiap kelompok sosial memiliki pola sendiri yang dapat diterima oleh kelompoknya. Anak pun belajar mempunyai peran dan memahami peran-peran yang ada di lingkungan sekitarnya, diharapkan ada peran sosial yang baik untuk orang tua dan anak maupun guru dan siswa.

c. Mengembangkan sikap-sikap sosial Untuk bersosialisasi, anak harus berlatih menyukai orang lain dan aktivitas sosial. Setelah anak belajar menyukai orang lain dan aktivitas sosial, anak akan memiliki penyesuaian diri yang baik dan diterima sebagai anggota kelompok sosialnya. Berdasarkan pendapat-pendapat yang tertera di atas dapat disimpulkan bahwa tingkat kepedulian seseorang dapat berkurang disebabkan oleh pengaruh dari luar yang dapat berupa internet, sarana hiburan, tayangan TV, dan masuknya pengaruh dari budaya barat. Selain itu dapat terpengaruh karena adanya kegagalan dalam proses sosialisasi.

\section{g. Upaya Meningkatkan Kepedulian Sosial Pada Anak}

Upaya yang dapat dilakukan untuk meningkatkan kepedulian sosial pada anak menurut Buchari Alma, dkk (2010, 210-211) adalah:

a. Pembelajaran di rumah

Peranan keluarga terutama orang tua dalam mendidik sangat berpengaruh terhadap tingkah laku anak. Keluarga merupakan lingkungan pendidikan yang pertama dan utama.

Dikatakan sebagai pendidikan yang pertama karena pertama kali anak mendapatkan pengaruh pendidikan dari dan di dalam keluarganya. Sedangkan dikatakan sebagai pendidikan yang utama karena sekalipun anak mendapatkan pendidikan dari sekolah dan masyarakatnya, namun tanggung jawab kodrati pendidikan terletak pada orang tuanya (Wahyudin, 2008: 37)

Merujuk pada pendapat diatas, dapat dikatakan bahwa keluarga merupakan lingkungan pertama yang mengajarkan berbagai hal kepada seorang anak dan memiliki tanggung jawab yang utama 
untuk mendidik anak tersebut.Anak-anak biasanya akan meniru setiap tingkah laku orang tuanya. Seperti apa yang dijelaskan oleh Mulyani Sumantri \& Syaodih (2008: 239), anak semenjak usia balita suka meniru apa saja yang dia lihat, dari tindak tanduk orang tua, cara bergaul orang tua, cara berbicara atau berinteraksi di lingkungan sekitar, cara orang tua menghadapi teman, tamu dan sebagainya. Oleh karena itu, orang tua harus menjadi contoh tauladan bagi anak-anaknya.

b. Pembelajaran di lingkungan masyarakat

Belajar saling peduli menjadi sangat penting peranannya dalam memaksimalkan perkembangan sosial manusia. Banyak sekali contoh di masyarakat yang dapat diikuti oleh orang tua dalam rangka mengasah kepedulian sosial anak. Salah satunya adalah menghadiri ulang tahun anak, membantu anak yang kesusahan, berbagi pada fakir dan miskin, memberi sesuatu jika mampu. Dengan hal itu maka anak akan dapat berbagi melalui interaksi kegiatan sosial di masyarakat serta dapat melatih kita untuk saling memahamisatu sama lain.

c. Pembelajaran di sekolah

Sekolah sebagai penyelenggara pendidikan memiliki potensi untuk memberikan pendidikan nilai kepedulian sosial melalui guru dan seluruh penyangga kepentingan sekolah. Penanaman nilai dapat diintegrasikan pada setiap mata pelajaran supaya nilai benar-benar terinternalisasi pada siswa. Guru menjadi faktor utama dalam pengintegrasian nilai-nilai di sekolah. Selain itu sekolah juga memiliki berbagai macam kegiatan baik yang berhubungan dengan di dalam maupun di luar sekolah dengan melibatkan warga sekitar yang dapat menumbuhkan sikap kepedulian sosial, misalnya kegiatan, infak, kerja bakti dengan warga sekitar sekolah dan lain-lain yang merupakan wadah bagi siswauntuk meningkatkan rasa kepedulian, baik sesama warga sekolah maupun masyarakat luas. Kegiatan dengan melibatkan pihak luar sekolah ini sesuai dengan yang dikatakan Maman Rachman (1997: 176-183) bahwa sekolah perlu mengadakan hubungan baik dan kerja sama dengan komunitas lingkungan sekitar. Masyarakat diharapkan dapat membantu dan bekerja sama dengan sekolah agar program sekolah dapat berjalan 
dengan lancar dan oleh sebab itu hubungan yang saling menguntungkan antara sekolah dan masyarakat perlu dibina secara harmonis.

\section{h. IMPLEMENTASI KEPEDULIAN SOSIAL}

\section{a. Implementasi terhadap diri sendiri}

Setelah membaca topik diatas, sudah selayaknya kita harus menumbuhkan rasa kepedulian sosial agar bisa menjadi individu yang peka terhadap masalah-masalah sosial yang sedang terjadi. Kita tidak boleh bersikap acuh tak acuh terhadap permasalahan sosial yang terjadi di lingkungan kita. Berbagai cara dapat dilakukan misalnya dengan ikut menjadi panitia dalam acara seperti amal dan bakti sosial. Dengan begitu kita bisa menumbuhkan rasa kepedulian terhadap sesama dan juga kepekaan kita.

\section{b. Implementasi Terhadap Masyarakat}

Setelah berusaha mengimplementasikan kepedulian sosial terhadap diri sendiri, selanjutnya adalah bagaimana menerapkan sifat kepedulian sosial dalam bermasyarakat. Penerapan dalam masyarakat dapat di implementasikan dengan lingkungan sekitar kita karena masih banyak orang yang kurang peduli pada sesama yang tidak menghiraukan orang yang membutuhkan bantuan dan mereka hanya tak acuh pada sesama mereka. Seharusnya kita lebih peduli agar tidak ada orang yang kesusahan lagi. Implementasi peduli terhadap sesama bisa dilakukan dari hal-hal kecil yang kelihatannya sepele, seperti berbagi kebahagiaan dengan orang sekitar, rutin bersedekah,

\section{c. Membangun Kepedulian Sosial Pada Anak}

Kepedulian sosial tidak banyak saat ini dilakukan oleh banyak orang. Banyak yang merasakan makin sedikit orang yang peduli pada sesama dan cenderung menjadi seorang individualistis yang mementingkan diri sendiri. Namun begitu, siapapun orangnya tentu tidak mau anak menjadi orang yang apatis, Pastilah setiap orangtua menginginkan anaknya menjadi seorang yang berjiwa sosial tinggi dan senang membantu sesamanya.

Berjiwa sosial dan senang membantu merupakan sebuah ajaran yang universal dan dianjurkan oleh semua agama. Meski 
begitu, kepekaan untuk melakukan semua itu tidak bisa tumbuh begitu saja pada diri setiap orang karena membutuhkan proses melatih dan mendidik. Di sini pola pengasuhan berperan sangat penting, terutama yang dilakukan oleh orangtua saat melakukan kepedulian sosial terhadap sesama di lingkungan sekitar dan sudah tentu anak akan mencontoh hal tersebut yang sering Anda lakukan.

Memiliki jiwa kepedulian sosial sangat penting bagi setiap orang karena kita tidak bisa hidup sendirian di dunia ini, begitu juga pentingnya bagi anak karena kelak mereka pun akan hidup mandiri tanpa orangtuanya lagi. Dengan jiwa sosial yang tinggi, mereka akan lebih mudah bersosialisasi serta akan lebih dihargai. Bayangkan bila setiap orang telah luntur jiwa sosialnya. Kehidupan akan kacau, berlaku hukum rimba, kaum tertindas makin tertindas, semua orang mengedepankan ego masing-masing dan keadilan pun akan menjadi hal yang sangat mahal (Hamid, 2009: 28).

Apa yang dilakukan siswa dalam masyarakat salah satunya adalah bergaul dengan teman. Proses bersosialisasi dalam interaksi sosial para siswa dapat mempengaruhi minat belajar siswa itu sendiri. Karena, interaksi Sosial adalah hubungan dinamis yang mempertemukan orang dengan orang, kelompok dengan kelompok maupun orang dengan kelompok manusia (Djamarah, 2000: 63).

Uraian di atas menegaskan bahwa interaksi sosial siswa usia sekolah perlu menjadi perhatian bagi setiap elemen masyarakat, oleh karena itu ada beberapa hal yang perlu dicermati untuk membangun kepedulian sosial anak antara lain:

a. Menunjukkan atau memberikan contoh sikap kepedulian sosial. Memberikan nasihat pada anak tanpa disertai dengan contoh langsung Anda tidak akan memberikan efek yang besar. Jika sikap Anda dalam kehidupan sehari-hari menunjukkan sikap peduli pada sesama maka kemungkinan besar anak akan mengikutinya.

b. Melibatkan anak dalam kegiatan sosial.

Biasakan untuk mengajak anak dalam kegiatan sosial seperti memberikan sumbangan ke panti asuhan dan berzakat.

c. Tanamkan sifat saling menyayangi pada sesama.

Menanamkan sifat saling menyayangi pada sesama dapat diterapkan dari rumah, misalnya dengan membantu orang tua, kakak ataupun menolong teman yang jatuh. 


\section{MENUMBUHKAN SIKAP PEDULI PADA ANAK...}

d. Memberikan kasih sayang pada anak.

Dengan orangtua memberikan kasih sayang maka anak akan merasa aman dan disayangi, dengan hal itu kemungkinan anak akan memiliki sikap peduli pada orang lain yang ada di sekitarnya. Sedangkan anak yang kurang mendapatkan kasih sayang justru akan cenderung tumbuh menjadi anak yang peduli pada dirinya sendiri.

e. Mendidik anak untuk tidak membeda-bedakan teman.

Mengajarkan anak untuk saling menyayangi terhadap sesama teman. Beri pengertian bahwa semua orang itu sama yaitu ciptaan Tuhan.

f. Banyak orang yang beranggapan bahwa sikap kepedulian sosial tumbuh dalam kepribadian seseorang dimulai pada saat beranjak dewasa. Tapi kenyataannya, sikap kepedulian sosial dapat diajarkan atau diterapkan pada anak mulai sejak dini. Jadi mulailah dari sekarang untuk mendidik anak agar memiliki kepribadian yang baik dengan sikap kepedulian sosial. Perilaku yang baik akan tertanam dalam diri seseorang jika sering dilatih dan diterapkan dalam kehidupan sehari-hari.

Pendapat lain mengatakan bahwa Dengan menanamkan jiwa kepedulian sosial pada anak, maka setidaknya ada sedikit harapan di masa depan dimana anak-anak kita akan menjadi pemimpin untuk mewujudkan masyarakat yang saling tolong-menolong. Untuk menanamkan jiwa sosial tersebut pada anak Anda, sebagai orangtua harus lebih banyak melakukan praktek daripada hanya berteori, sehingga anak-anak kita akan mencontoh perbuatan-perbuatan nyata yang kita lakukan. Banyak hal yang dapat dipraktekkan untuk menanamkan jiwa sosial pada anak, antara lain :

a. Mengajak anak Anda menengok saudara atau tetangga yang sedang sakit.

b. Mengunjungi panti jompo.

c. Rutin bersedekah.

d. Berbagi kebahagiaan dengan anak-anak jalanan, misalnya saat ulang tahun.

e. Menyuguhi minuman pada tukang sampah yang mengangkut sampah dari rumah kita. 
f. Memberikan tumpangan pada teman atau tetangga yang tidak berkendaraan saat melakukan perjalanan yang sejalur dengan kita.

g. Berbagi makanan yang kita masak pada tetangga di sekitar yang kurang mampu.

h. Berbagi kebahagiaan di hari raya keagamaan dengan anak-anak di panti asuhan.

i. Memberikan sumbangan pada korban bencana alam, dll.

Contoh-contoh di atas merupakan sedikit saja dari apa yang bisa Anda lakukan untuk mendidik anak agar memiliki jiwa kepedulian sosial yang tinggi. Selain itu masih banyak kegiatan lain yang bisa Anda lakukan. Yang terpenting, lakukan semuanya dengan ikhlas tanpa mengharapkan imbalan apapun dan lakukan semampu Anda, tidak perlu memaksakan diri bila Anda memang tidak mampu. Dengan mencontoh dan melihat kegiatan-kegiatan sosial yang Anda lakukan, niscaya kelak sang anak juga akan menjadi orang yang berjiwa sosial dan menjadi kebanggaan keluarga. Selamat mendidik.

\section{KESIMPULAN}

Kepedulian sosial adalah suatu nilai penting yang harus dimiliki seseorang karena terkait dengan nilai kejujuran, kasih sayang, kerendahan hati, keramahan, kebaikan dan lain sebagainya. Dengan pesatnya kemajuan teknologi-teknologi modern yang bisa menghubungkan individu dengan individu lain tanpa batasan ruang dan waktu, membuat sebagian individu memiliki sifat individualistis yang dominan dikarenakan dampak dari perkembangan zaman dan teknologi ini. Contoh nyata yang dapat ditemukan adalah, individu maupun kelompok cenderung menertawai orang yang terjatuh daripada menolongnya terlebih dahulu. Namun, hal ini tidak berlaku apabila yang terjatuh adalah gadget canggih. Oleh karna itu, topik diatas sangat penting untuk kita pahami dan pelajari agar kepedulian sosial yang ada di kultur budaya kita bisa tumbuh kembali. 


\section{DAFTAR PUSTAKA}

Ahid, Nur. (2010). Pendidikan keluarga dalam perspektif Islam.Yokyakarta: Rineka Cipta

Ahmadi Abu dan Uhbiyati Nur.(2000) Ilmu Pendidikan. Jakarta: PT Rineka Cipta.

Alma Buchari, dkk. (2010). Pembelajaran Studi Sosial. Bandung: Alfabeta.

Darmiyati Zuchdi. (2011). Pendidikan Karakter dalam Prespektif Teori dan Praktek. Yogyakarta: UNY Press

Djamarah, S.B. (2000).Guru dan Anak Didik dalam Interaksi Edukatif. Jakarta.Rineka Cipta.

Fuad Ihsan. (2003). Dasar-Dasar Kependidikan. Jakarta: Rineka Cipta Gunawan Ary H.. (2000). Sosiologi Pendididkan. Jakarta: Rineka Cipta Hamid, Abdul.2009. Ilmu Akhla. Bandung:Pustaka Cipta.

Hera Lestari Malik, Agus Taufik \& Puji Lestari Prianti. (2008). Pendidikan Anak SD. Jakarta: Universitas Terbuka.

Listyarti Retno. 2012. Pendidikan Karakter dalam metode Aktif, Inovatif dan Kreatif. Jakarta: Esensi.

Narwanti Sri. (2011). Pendidikan Karakter.Yogyakarta: Familia.

Nasution, 1983. Sosiologi Pendidikan, Bandung , Jammars.

Mulyani Sumantri \& Nana Syaodih. (2008). Perkembangan Peserta Didik. Jakarta: Universitas Terbuka

Rachman Maman. (1997). Manajemen Kelas. Semarang:Pendidikan Dan Kebudayaan Direktorat Jendral Pendidikan Tinggi Proyek Pendidikan Guru Sekolah Dasar

Pusat Studi PAUD Lembaga Penelitian Universitas Negeri Yogyakarta. 2009. Buku Panduan Program Pembelajaran untuk Menstimulasi Keterampilan Sosial Anak Bagi Pendidik Taman Kanak-kanak. Yogyakarta: Logung Pustaka

Rohman Arif. (2009). Memahami Pendidikan \& Ilmu pendidikan. Yogyakarta: LaksBang Mediatama Yogyakarta.

Setiadi, Elly M. Kama A. Hakam, Ridwan Effendi. 2012. Ilmu Sosial dan Budaya Dasar, Jakarta: Kencana.

Soekanto, Soerjono. (1992). Sosiologi Suatu Pengantar ,Jakarta: Rajawal. 
A.Tabi'in

Wahyudin Din. (2008). Pengantar Pendidikan. Jakarta: Universitas Terbuka 